\title{
Physio-biochemical Variability of Pomegranate Cuttings Collected from Northern India
}

\author{
Rajkumar*, Anshuman Singh, Anita Mann and R. K. Yadav
}

ICAR-Central Soil Salinity Research Institute, Karnal-132001(Haryana), India

*Corresponding author

\section{A B S T R A C T}

\section{Keywords}

Physio-biochemical variability,

Pomegranate, Salt tolerant

Article Info

\section{Accepted:}

15 January 2020

Available Online:

10 February 2020
Pomegranate (Punica granatum L.) is one of the hardy crop and may have potential to be grown under salt affected areas although salinity could be a limiting factor for growth and yield in its cultivation. Thus, screening of salt tolerant genotype of pomegranate is one of the most important aspects for the best utilization and improving the productivity of salt affected soils. To assess the variability among different genotypes on the basis of vegetative growth characteristics, biochemical and physico-chemical parameters etc. twenty genotypes of pomegranate were evaluated under nursery conditions. The pomegranate genotypes collected from Jaipur (03), Ajmer (05), Rajasmand (04), Udaipur (03), Pali (01), Jodhpur (01), Nagour (01), Bikaner (02), respectively were grown in polybags filled with partially reclaimed sodic soils. Different biochemical and physiological parameters like proline $(\mu \mathrm{g} / \mathrm{g} \mathrm{FW}), \mathrm{RWC}(\%)$, chlorophyll $(\mathrm{mg} / \mathrm{gFW}), \mathrm{Na}^{+}$ $(\%), \mathrm{K}^{+}(\%), \mathrm{K}^{+} / \mathrm{Na}^{+}$and vegetative growth parameters like number of roots, length of roots $(\mathrm{cm})$, number and length of shoots and number of leaves were recorded after four months of planting the cuttings. Significant variations among these genotypes indicated inherited gain against salinity tolerance. On the basis of the above said parameters, this experiment may provide indicators for selection of salt tolerant pomegranate genotypes for salt affected soils.

\section{Introduction}

Salt affected soils are an important ecological entity of Indian agriculture. With increasing population pressure and competition for good quality lands, intensive agriculture is being pushed more and more into marginal environments. The arable lands are shrinking due to developmental activities and offer little scope for raising horticultural crops. There is no option other than bringing marginal and salt affected lands under cultivation and utilizing them judiciously through horticultural practices. By growing horticultural crops on highly deteriorated salt affected soils with saline water may improve economic conditions of farmers. Several salt tolerant fruit trees have been identified for saline and alkaline lands like Ber (Hooda et al., 1990), Date-palm (Furr et al., 1966), Fig (Patil and Patil, 1983a), Guava (Patil et al., 1984), Jamum (Patil and Patil, 1983b), Olive (Taha et al., 1972) and Pomegranate (Maas and Hoffmann, 1976; Munns, 2002) etc. 
Pomegranate (Punica granatum L.) belonging to family Punicaceae is a delicious and desert table fruit of tropical and subtropical regions of the world. It is native to Persia (Iran), Afghanistan and Baluchistan. In India, it is being grown from Kanyakumari to Kashmir but the commercial plantations of pomegranate exists only in Maharashtra, Gujarat, Rajasthan, Karnataka and to a limited extent in Andhra Pradesh, Madhya Pradesh, Uttar Pradesh, Punjab, Haryana and Tamil Nadu etc. Owing to its xerophytic characteristics it is very suitable crop for dry, rainfed, pastured and undulating land, where other fruit crops cannot grow successfully. It provides high yield and more income per unit area with low input in arid and semi-arid regions. At present India's pomegranate production is 2845 thousand MT from an area of 234 thousand hectare in Maharashtra, Karnataka, Tamil Nadu, Rajasthan, Punjab and Haryana etc. with an average productivity of $12.16 \mathrm{MT} / \mathrm{ha}$ (Anonymous, 2019) and there is further scope for its expansion in adjacent areas of saline soils in India. India ranks first in the world with respect to pomegranate area and production while in productivity, Spain ranks first $(18.5 \mathrm{t} / \mathrm{ha})$ followed by the USA (18.3 t/ha). Iran contributes maximum to exports $(60,000$ t/year) followed by India (35,176 t). During 2016-17, India exported 49.76 thousand MT pomegranate of worth Rs. 49041.55 Lakh. Despite Spain having very little area (2000 ha), its export share is $37.8 \%$ of total production $(37,000 \mathrm{t})$ followed by Israel $(23.5 \%)$ and the USA $(15.5 \%)$ while India has the lowest share (Silvaa et al., 2013). Due to wider adaptability of pomegranate in tropical, subtropical, arid and temperate regions it can also be one of the most important fruit crop for salt affected soils. Salt affected soils and irrigation water are currently most severe abiotic limiting factors for the cultivation of horticultural crops. Where the salinization has been developed through irrigation, that causes decreasing crop yields and land degradation as a result of excess salts being present in water during irrigation (Ayers and Westcot, 1985). Currently, most of pomegranate cultivation is in arid and semi-arid regions of the world, where soil salinity and water stress are the main limitations of appropriate yield production. There is an increasing attention towards salinity and more than 800 million hectare of lands has been affected that is equivalent to $6 \%$ of total (Munns, 2002).

The evidence of salinity tolerance depends on the physiological and biochemical processes occurring in plants. Thus, the complex physiology of salt tolerance and the variation between species on the basis of biochemical mechanisms of salinity tolerance may be the promising selection criteria (Ashraf and Harris, 2004). Despite the economic importance of pomegranate and its byproducts, the study on the response of pomegranate cultivars to salinity stress has not been studied in India so far. Also, the most resistant native cultivars of pomegranate to soil salinity are unknown for gardeners in the saline soil regions. Therefore, with the objective to identify and introduce the mosttolerant Indian cultivars, rootstocks of pomegranate to different salinity levels have been analyzed in this study.

\section{Materials and Methods}

The experiment was carried out from August 2015 to February, 2016 at Experimental Farm of ICAR-Central Soil Salinity Research Institute, Karnal, located at the latitude 29.43, longitude 76.58, altitude $245 \mathrm{~m}$ elevation above the mean sea level. The experimental design was laid out in randomized blocks, in a $20 \times 3$ factorial scheme, for twenty genotypes of Pomegranate with three replications. During last week of August, 2015 cuttings of twenty (18 unknown and 02 known) genotypes were collected from Jaipur (03), 
Ajmer (05), Rajasmand (04), Udaipur (03), Pali (01), Jodhpur (01), Nagour (01), Bikaner (02), respectively as shown in Table 1 . These cuttings were grown in partially reclaimed sodic soils filled polybags which were kept on polyethene sheets to avoid leaching of salts. Different growth parameters such as number of roots, length of roots $(\mathrm{cm})$, number of shoots, length of shoots and number of leaves as well as physico-biochemical parameters i.e. RWC (\%), chlorophyll (mg/g FW), proline $(\mu \mathrm{g} / \mathrm{g} \mathrm{FW}), \mathrm{Na}^{+}(\%), \mathrm{K}^{+}(\%), \mathrm{K}^{+} / \mathrm{Na}^{+}$were recorded after four months of planting the cuttings. Analysis of data was done using at $5 \%$ level of significance with the help of SAS (Version 9.3, SAS Institute Inc., Cary, NC, USA).

\section{Results and Discussion}

\section{Vegetative growth parameters}

Significant variability among different pomegranate genotypes were recorded among number of roots as depicted in table 2 . Genotype, Jaipur 1 had maximum number of roots (76.67), followed by 'Ajmer 2' (70.67) and 'Jaipur 2' (70.33), while minimum number of roots were found in 'Pali 1' (56.33). The length of root was measured with measuring scale. Maximum length was recorded in genotype 'Rajasmand 3' (20.90 $\mathrm{cm})$ followed by 'Nagaur' $(20.73 \mathrm{~cm})$ and 'Rajasmand 2' (20.70 cm), however, minimum root length was found in 'Ajmer 5' $(19.10 \mathrm{~cm})$. Similar findings have been reported earlier about decrease in growth biomass of roots, shoots and leaves due to loss of turgor and its associated cell wall tension relaxation with increasing $\mathrm{NaCl}$ level in many agricultural crops (Anthraper and Dubois, 2003, Aragües et al., 2004, Sairam and Tyagi, 2004, Hajer et al., 2006).

Maximum number of shoots were found in genotypes Udaipur 2 (5.33), followed by
'Jaipur 3' (5.13) and 'Ajmer 3' (4.77), respectively; however minimum number of shoots were found in 'Nagour' (3.50). Increase in number of shoots might be increased nutrient uptake that could affects the cell division in the vascular cambium, cell expansion and control of differentiation into different types of cambial (Devi et al., 2016). Plant growth under salt stress might be due to osmotic stress, leaf injuries, and reduced photosynthesis (Wahome et al., 2001).The growth of pistachio seedlings under salt stress conditions significantly reduced shoot height, crown diameter, leaf number, and dry mass of the seedlings under 100 and $150 \mathrm{mMNaCl}$ treatments (Mirfattahiet al., 2017). Maximum shoot length was observed in genotype Jaipur $1(15.73 \mathrm{~cm})$, followed by 'Udaipur 1' $(14.87 \mathrm{~cm})$ and 'Ajmer 2' $(14.17 \mathrm{~cm})$, respectively; however minimum length of shoots were found in Bhagwa $(8.63 \mathrm{~cm})$. Such changes appear to be related to changes in protein composition of cell walls (Bozarth., 1987; Singh et al., 1987). However, the relationship between reductions of growth rate be more complex as growth is actively controlled independently of the sensing of turgor pressure (Bressan et al., 1982; Boyer et al., 1985), via changes in cell wall extensibility, osmotic inhibition of water availability, toxic effects of high salts ions and disturbance of the uptake and translocation of nutritional ions (Ates and Tekeli, 2007). Maximum numbers of leaves were found in genotype 'Jodhpur 1' (185.00), followed by 'Jaipur 1' (173.33) and 'Ajmer 1' (172.50), with minimum numbers of leaves in 'Rajasmand 3 \& 4' (115), respectively. The number of leaves is related to the number and length of sprouts of cutting which depends on hydrolysis of reserve food materials for the maintenance of root and shoot balance. The results of the present study are in line with the findings of Chauhan and Maheswari (1970), Stancatoet al., (2003) and Kaur and Kaur (2016). 


\section{Physico-biochemical traits}

The first physiological indicator of abiotic stress on plants is relative water content (Kumar et al., 2017; Pooja et al., 2019). In pomegranate, maximum RWC (table 3) was found in genotype 'Jaipur 1' (92.55\%), followed by 'Jaipur 2' (92.07\%), and 'Ajmer 3' (91.54 \%), however minimum RWC (81.46 $\%$ ) was reported in Bhagwa. The maintenance of RWC is also related to osmoregulation under stress conditions since water deficiency or osmotic stress induces changes in the cell metabolic activity (Kumar et al., 2018; Makarana et al., 2019) and reduces cell division and expansion (Taiz and Zeiger, 2006) leading to plant growth inhibition. Similarly, Hokmabadi et al., (2005) reported that maintenance of RWC in pistachio leaves was due to accumulation of osmolytes and osmotic adjustment under salt stress. On the other hand, Mirfattahi et al., (2017) reported that relative water content (RWC) and water potential of the leaves were not affected by the $\mathrm{NaCl}$ treatments in pistachio genotypes in soilless culture. The morphological observations revealed little variation in leaf greenness which was further confirmed by non-significant difference in chlorophyll content among different genotypes (table 3). However, the maximum chlorophyll content was found in genotype 'Udaipur 3' $(0.62 \mathrm{mg}$ $\left.\mathrm{g}^{-1} \mathrm{FW}\right)$, followed by 'Ajmer 4' $\left(0.56 \mathrm{mg} \mathrm{g}^{-1}\right.$ FW), and 'Rajasmand1' (0.55 $\mathrm{mg} \mathrm{g}^{-1}$ FW), with minimum chlorophyll content (0.34 $\mathrm{mg} \mathrm{g}^{-1} \mathrm{FW}$ ) in 'Udaipur 2'. A negative correlation of chlorophyll concentration with salinity i.e. a decline in chlorophyll content in response to an increasing salt stress has been reported in citrus (Melgar et al., 2008) and in pomegranate (Mastrogiannidou et al., 2016). Salinity may influence absorption of ions, such as $\mathrm{Mg}^{2+}$ and $\mathrm{Fe}^{2+}$, which are involved in chlorophyll formation and salinity leads to depression of $\mathrm{Mg}$ concentration in plants under saline environment (Sivstev et al.,
1973; Mastrogiannidou et al., 2016). The chlorophyll degrading enzyme chlorophyllase is more active under salt stress (Singh et al., 2016, Kumar et al., 2016). Papadakis et al., (2007) reported significant reductions of chlorophyll content in $\mathrm{NaCl}$-treated cherry plants containing $\mathrm{Na}$ and $\mathrm{Cl}$ higher than $5 \mathrm{mg}$ $\mathrm{g}^{-1}$ and $20 \mathrm{mg} \mathrm{g}^{-1}$, respectively. Whereas, Doring and Ludders (1986b) observed lowest chlorophyll contents of pomegranate leaves at medium salt level $\left(60 \mathrm{mMNaCl}\right.$ or $\left.\mathrm{Na}_{2} \mathrm{SO}_{4}\right)$; though Mastrogiannidou et al., (2016) indicated a noticeable decline in the chlorophyll concentration of plants treated with $120 \mathrm{mMNaCl}$ or $\mathrm{Na}_{2} \mathrm{SO}_{4}$.Proline, an indicator of the stress condition and its accumulation is important for water conservation in tissues and preventing cytoplasm dehydration under osmotic stress (Lata et al., 2017, 2019; Pooja et al., 2019). Although variation in proline content was seen in different genotypes but it was nonsignificant. Maximum proline content was found in genotype 'Jaipur 1' $\left(212.97 \mu \mathrm{g} \mathrm{g}^{-1}\right.$ FW) followed by 'Ajmer 2' (187.73 $\mu \mathrm{g} \mathrm{g}^{-1}$ FW) and 'Ajmer 3' (177.96 $\left.\mu \mathrm{g} \mathrm{g}^{-1} \mathrm{FW}\right)$, however, minimum proline content (113.17 $\mu \mathrm{g} \mathrm{g}^{-1} \mathrm{FW}$ ) was reported in 'Pali 1' (table 3). As per earlier reports, proline accumulation occurs under stress conditions and proline being an osmoprotectant, provides tolerance to plants towards adverse growth conditions (Singh et al., 2018). Taking this into consideration, the genotypes having higher proline show possibility of better growth under salt affected conditions and hence can be selected for further studies. Many investigators found increased proline accumulation in various plants exposed to salt stress (Karimi et al., 2005; Chatzissavvidis et al., 2014). Similarly, Mirfattahi et al., (2017) found significant increase in leaf proline concentration under severe salt stress in pistachio genotypes. A significant difference was reported in $\mathrm{Na}^{+}$and $\mathrm{K}^{+}$contents among different pomegranate genotypes as shown in 
Table 2. The minimum $\mathrm{Na}^{+}$content was found in genotype 'Ajmer 2' (0.15\%), followed by 'Jaipur 2' $(0.17 \%)$, whereas maximum $\mathrm{Na}^{+}$ content $(0.35 \%)$ was reported in 'Ajmer 4'\&'Ajmer 5', 'Pali1' and 'Jodhpur 1', respectively. The maximum $\mathrm{K}^{+}$content was found in genotype 'Jaipur 1' (8.71 \%), followed by 'Rajasmand 3' (6.27) and 'Rajasmand 1' (5.96\%), with minimum $\mathrm{K}^{+}$ content $(2.81 \%)$ in enotype 'Pali 1 '. The ratio of sodium to potassium or vice-versa determines the tolerance level of plants under stress conditions, lower the ratio more tolerant is the plant. Maximum $\mathrm{K}^{+} / \mathrm{Na}^{+}$ratio was found in genotype 'Jaipur 1'(45.50 \%), followed by 'Ajmer 2' (33.28\%) and 'Jaipur 2'(26.66\%), respectively; however minimum $\mathrm{K}^{+} / \mathrm{Na}^{+}$ratio was reported in 'Pali 1 ' $(8.15 \%)$. These pomegranate genotypes showed significant variations in level of tolerance against adverse effects of $\mathrm{Na}^{+}$ions due to varied uptake capacity and accumulation of these ions into leaf tissues.

Table.1 Survey, collection and morphology of pomegranate genotypes

\begin{tabular}{|c|c|c|c|c|}
\hline DISTRICT & LOCATION & COORDINATES & pH & $\begin{array}{l}\text { ECe } \\
\left(\mathrm{dsm}^{-1}\right)\end{array}$ \\
\hline \multirow[t]{3}{*}{ JAIPUR } & AKEDA, JAIPUR & $27.0983^{\circ} \mathrm{N}, 75.7207^{\circ} \mathrm{E}$ & 7.73 & 2.3 \\
\hline & 6 NO. ROAD, JAIPUR & $27.0086^{0} \mathrm{~N}, 75.4785^{0} \mathrm{E}$ & 7.40 & 4.1 \\
\hline & 6 NO. ROAD, JAIPUR & $27.0086^{0} \mathrm{~N}, 75.4785^{\circ} \mathrm{E}$ & 7.07 & 3.6 \\
\hline \multirow[t]{5}{*}{ AJMER } & TABIJI, AJMER & $26.2201^{0} \mathrm{~N}, 74.3548^{0} \mathrm{E}$ & 7.20 & 3.2 \\
\hline & TABIJI, AJMER & $26.2204^{0} \mathrm{~N}, 74.3549^{0} \mathrm{E}$ & 7.73 & 2.7 \\
\hline & TABIJI, AJMER & $26.0220^{0} \mathrm{~N}, 74.0354^{0} \mathrm{E}$ & 7.68 & 2.9 \\
\hline & PUSHKAR, AJMER & $26.0290^{\circ} \mathrm{N}, 74.0339^{0} \mathrm{E}$ & 7.40 & 3.2 \\
\hline & PUSHKAR, AJMER & $26.0291^{0} \mathrm{~N}, 74.0338^{0} \mathrm{E}$ & 7.90 & 3.9 \\
\hline \multirow[t]{4}{*}{ RAJASMAND } & BALLI JASSA KHERA & $25.0483^{0} \mathrm{~N}, 74.0050^{0} \mathrm{E}$ & 7.70 & 4.1 \\
\hline & SELMA, BALLI JASSA KHERA & $24.0344^{0} \mathrm{~N}, 73.0424^{0} \mathrm{E}$ & 7.90 & 2.4 \\
\hline & SARSONIA, RAJASMAND & $25.0667^{\circ} \mathrm{N}, 73.8833^{\circ} \mathrm{E}$ & 7.80 & 3.5 \\
\hline & AUDAN MIRAJ, RAJASMAND & $24.0547^{\circ} \mathrm{N}, 73.0481^{\circ} \mathrm{E}$ & 7.78 & 2.8 \\
\hline \multirow[t]{3}{*}{ UDAIPUR } & UDAIPUR & $24.5712^{\circ} \mathrm{N}, 73.6915^{\circ} \mathrm{E}$ & 8.04 & 2.3 \\
\hline & UDAIPUR & $24.5712^{\circ} \mathrm{N}, 73.6915^{\circ} \mathrm{E}$ & 8.07 & 3.8 \\
\hline & SYRA, UDAIPUR & $24.9863^{\circ} \mathrm{N}, 73.4123^{\circ} \mathrm{E}$ & 7.96 & 3.9 \\
\hline PALI & SAJRI, PALI & $25.1326^{\circ} \mathrm{N}, 73.4534^{\circ} \mathrm{E}$ & 8.13 & 3.8 \\
\hline JODHPUR & $\begin{array}{l}\text { NAGAUR ROAD, TOOR KI } \\
\text { BADI }\end{array}$ & $25.0094^{0} \mathrm{~N}, 73.0274^{0} \mathrm{E}$ & 7.89 & 4.1 \\
\hline NAGAUR & RAIDHANU, NAGAUR & $27.2024^{0} \mathrm{~N}, 73.7544^{0} \mathrm{E}$ & 7.50 & 3.2 \\
\hline \multirow[t]{2}{*}{ BIKANER } & GANESH & $28.0067^{0} \mathrm{~N}, 73.0208^{0} \mathrm{E}$ & 7.96 & 2.7 \\
\hline & BHAGWA & $28.0067^{0} \mathrm{~N}, 73.0208^{0} \mathrm{E}$ & 7.85 & 2.8 \\
\hline
\end{tabular}


Table.2 Root and shoot characters in pomegranate genotypes at vegetative growth stage

\begin{tabular}{|c|c|c|c|c|c|}
\hline Genotypes & $\begin{array}{l}\text { Number of } \\
\text { Roots }\end{array}$ & Root Length (cm) & $\begin{array}{l}\text { Number of } \\
\text { Shoots }\end{array}$ & $\begin{array}{c}\text { Shoot Length } \\
(\mathrm{cm})\end{array}$ & $\begin{array}{l}\text { Number of } \\
\text { Leaves }\end{array}$ \\
\hline Jaipur 1 & $76.67 \pm 5.667$ & $20.67 \pm 1.245$ & $4.67 \pm 0.987$ & $15.73 \pm 1.32$ & $173.33 \pm 24.253$ \\
\hline Jaipur 2 & $70.33 \pm 4.055$ & $19.50 \pm 0.2$ & $4.57 \pm 0.467$ & $13.80 \pm 1.501$ & $132.50 \pm 30.721$ \\
\hline Jaipur 3 & $66.67 \pm 3.383$ & $19.43 \pm 1.313$ & $5.13 \pm 0.433$ & $10.93 \pm 1.521$ & $132.50 \pm 5.0$ \\
\hline Ajmer 1 & $65.00 \pm 3.215$ & $20.47 \pm 0.524$ & $4.57 \pm 0.467$ & $12.63 \pm 0.26$ & $172.50 \pm 24.109$ \\
\hline 'Ajmer 2' & $70.67 \pm 3.712$ & $20.27 \pm 0.865$ & $4.27 \pm 0.956$ & $14.17 \pm 1.855$ & $155.00 \pm 40.927$ \\
\hline 'Ajmer 3' & $67.33 \pm 1.856$ & $19.47 \pm 1.471$ & $4.77 \pm 0.406$ & $10.17 \pm 2.252$ & $137.50 \pm 22.22$ \\
\hline Ajmer 4 & $60.67 \pm 4.91$ & $20.63 \pm 0.549$ & $4.57 \pm 0.467$ & $12.80 \pm 0.862$ & $132.50 \pm 5.0$ \\
\hline Ajmer 5 & $59.33 \pm 0.667$ & $19.10 \pm 1.137$ & $4.03 \pm 0.667$ & $13.13 \pm 0.780$ & $127.50 \pm 8.66$ \\
\hline $\begin{array}{l}\text { Rajasmand } \\
1\end{array}$ & $64.33 \pm 2.404$ & $20.67 \pm 0.884$ & $4.10 \pm 0.0$ & $11.73 \pm 0.521$ & $150.00 \pm 22.5$ \\
\hline $\begin{array}{l}\text { Rajasmand } \\
2\end{array}$ & $61.67 \pm 1.856$ & $20.70 \pm 1.002$ & $3.73 \pm 1.033$ & $12.60 \pm 2.656$ & $155.00 \pm 40.927$ \\
\hline Udaipur 1 & $64.33 \pm 1.764$ & $19.47 \pm 1.004$ & $4.57 \pm 0.467$ & $14.87 \pm 1.453$ & $127.50 \pm 30.311$ \\
\hline Udaipur 2 & $64.67 \pm 2.603$ & $20.07 \pm 0.949$ & $5.33 \pm 0.328$ & $13.80 \pm 1.069$ & $137.50 \pm 22.22$ \\
\hline $\begin{array}{l}\text { Rajasmand } \\
3\end{array}$ & $66.33 \pm 1.667$ & $20.90 \pm 0.794$ & $4.10 \pm 0.808$ & $10.10 \pm 1.405$ & $115.00 \pm 20.463$ \\
\hline $\begin{array}{l}\text { Rajasmand } \\
4\end{array}$ & $65.67 \pm 1.667$ & $19.73 \pm 1.44$ & $4.47 \pm 0.96$ & $10.20 \pm 1.137$ & $115.00 \pm 6.614$ \\
\hline Udaipur 3 & $62.67 \pm 3.528$ & $20.53 \pm 0.935$ & $4.77 \pm 0.406$ & $11.13 \pm 1.763$ & $132.50 \pm 34.731$ \\
\hline Pali 1 & $56.33 \pm 3.283$ & $20.10 \pm 0.866$ & $4.03 \pm 0.067$ & $12.07 \pm 0.133$ & $150.00 \pm 30.311$ \\
\hline Jodhpur 1 & $57.33 \pm 2.667$ & $19.60 \pm 1.012$ & $4.67 \pm 0.987$ & $12.20 \pm 2.103$ & $185.00 \pm 5.0$ \\
\hline Nagaur & $61.33 \pm 2.728$ & $20.73 \pm 0.41$ & $3.50 \pm 0.416$ & $10.57 \pm 1.633$ & $127.50 \pm 30.311$ \\
\hline Ganesh & $60.33 \pm 2.906$ & $20.57 \pm 0.467$ & $3.63 \pm 0.467$ & $12.33 \pm 2.167$ & $137.50 \pm 5.0$ \\
\hline Bhagwa & $57.67 \pm 4.702$ & $20.27 \pm 1.703$ & $4.70 \pm 0.416$ & $8.63 \pm 1.33$ & $150.00 \pm 15.612$ \\
\hline $\begin{array}{l}\text { General } \\
\text { Mean }\end{array}$ & 63.83 & 20.14 & 4.41 & 12.18 & 142.29 \\
\hline $\mathrm{CV}(\%)$ & 8.61 & 8.94 & 25.45 & 22.57 & 29.50 \\
\hline $\begin{array}{l}\text { CD at 5\% } \\
\pm \text { SE (d) }\end{array}$ & $9.14 \pm 4.499$ & NS & NS & NS & NS \\
\hline
\end{tabular}

The non-significant mean values have at least one common letter at $(\mathrm{p}<0.05)$ using Tukey`s Test 
Table.3 Biochemical and Physico-chemical parameters in pomegranate genotypes

\begin{tabular}{|c|c|c|c|c|c|c|}
\hline Genotypes & $\begin{array}{c}\text { Proline }\left(\mu \mathrm{g} \mathrm{g} \mathrm{g}^{-1}\right. \\
\text { FW) }\end{array}$ & RWC (\%) & $\begin{array}{l}\text { Chlorophyll } \\
\text { (mg g }{ }^{-1} \text { FW) }\end{array}$ & $\mathrm{Na}^{+}(\%)$ & $\mathbf{K}^{+}(\%)$ & $\mathrm{K}^{+} / \mathrm{Na}^{+}$ \\
\hline Jaipur 1 & $212.97 \pm 14.83$ & $92.55 \pm 1.176$ & $0.529 \pm 0.12$ & $0.22 \pm 0.006$ & $8.71 \pm 0.618$ & $39.73 \pm 3.516$ \\
\hline Jaipur 2 & $173.90 \pm 18.83$ & $92.07 \pm 1.055$ & $0.513 \pm 0.073$ & $0.167 \pm 0.057$ & $3.75 \pm 0.673$ & $26.66 \pm 8.853$ \\
\hline Jaipur 3 & $157.00 \pm 5.696$ & $91.22 \pm 2.472$ & $0.418 \pm 0.044$ & $\begin{array}{c}0.193 \pm \\
0.041\end{array}$ & $3.87 \pm 0.208$ & $21.80 \pm 4.542$ \\
\hline Ajmer 1 & $146.91 \pm 27.18$ & $90.14 \pm 1.307$ & $0.52 \pm 0.07$ & $0.267 \pm 0.074$ & $3.93 \pm 0.432$ & $20.18 \pm 9.843$ \\
\hline Ajmer 2 & $187.73 \pm 14.97$ & $90.90 \pm 1.528$ & $0.456 \pm 0.107$ & $0.147 \pm 0.037$ & $4.25 \pm 0.279$ & $33.28 \pm 8.665$ \\
\hline Ajmer 3 & $177.96 \pm 21.904$ & $91.54 \pm 2.598$ & $0.473 \pm 0.025$ & $0.227 \pm 0.027$ & $5.44 \pm 0.180$ & $24.52 \pm 2.359$ \\
\hline Ajmer 4 & $136.02 \pm 3.647$ & $88.86 \pm 0.094$ & $0.558 \pm 0.055$ & $0.353 \pm 0.007$ & $4.51 \pm 0.647$ & $12.82 \pm 2.066$ \\
\hline Ajmer 5 & $130.33 \pm 7.216$ & $87.05 \pm 6.563$ & $0.498 \pm 0.147$ & $0.347 \pm 0.007$ & $4.25 \pm 0.073$ & $12.25 \pm 0.226$ \\
\hline Rajasmand 1 & $140.27 \pm 2.899$ & $90.13 \pm 1.185$ & $0.554 \pm 0.033$ & $0.333 \pm 0.018$ & $5.96 \pm 1.46$ & $17.52 \pm 3.711$ \\
\hline Rajasmand 2 & $138.40 \pm 7.405$ & $87.50 \pm 1.442$ & $0.45 \pm 0.034$ & $0.26 \pm 0.031$ & $4.08 \pm 0.26$ & $16.44 \pm 3.17$ \\
\hline Udaipur 1 & $141.40 \pm 2.795$ & $89.37 \pm 2.888$ & $0.496 \pm 0.09$ & $0.29 \pm 0.041$ & $5.33 \pm 1.047$ & $19.96 \pm 6.917$ \\
\hline Udaipur 2 & $144.70 \pm 3.93$ & $90.69 \pm 1.141$ & $0.34 \pm 0.057$ & $0.28 \pm 0.042$ & $4.73 \pm 0.053$ & $17.65 \pm 2.594$ \\
\hline Rajasmand 3 & $169.39 \pm 17.362$ & $90.24 \pm 1.312$ & $0.47 \pm 0.051$ & $0.30 \pm 0.012$ & $6.27 \pm 1.747$ & $20.93 \pm 5.829$ \\
\hline Rajasmand 4 & $149.56 \pm 5.291$ & $89.68 \pm 0.356$ & $0.431 \pm 0.017$ & $0.20 \pm 0.012$ & $4.03 \pm 0.324$ & $20.10 \pm 0.82$ \\
\hline Udaipur 3 & $138.37 \pm 18.97$ & $90.09 \pm 2.162$ & $0.624 \pm 0.063$ & $0.33 \pm 0.018$ & $5.13 \pm 0.324$ & $15.55 \pm 1.638$ \\
\hline Pali 1 & $113.17 \pm 6.947$ & $81.59 \pm 3.853$ & $0.509 \pm 0.052$ & $0.35 \pm 0.018$ & $2.81 \pm 0.407$ & $8.15 \pm 1.292$ \\
\hline Jodhpur 1 & $115.95 \pm 7.191$ & $83.41 \pm 4.855$ & $0.507 \pm 0.06$ & $0.35 \pm 0.007$ & $3.75 \pm 0.428$ & $10.79 \pm 1.044$ \\
\hline Nagaur & $141.29 \pm 7.106$ & $87.33 \pm 0.725$ & $0.394 \pm 0.078$ & $0.28 \pm 0.020$ & $4.69 \pm 1.042$ & $16.99 \pm 4.28$ \\
\hline Ganesh & $131.37 \pm 14.468$ & $81.70 \pm 4.661$ & $0.413 \pm 0.048$ & $0.32 \pm 0.053$ & $4.58 \pm 0.252$ & $15.07 \pm 2.422$ \\
\hline Bhagwa & $126.91 \pm 7.486$ & $81.46 \pm 3.887$ & $0.597 \pm 0.09$ & $0.34 \pm 0.023$ & $4.26 \pm 0.34$ & $12.55 \pm 0.77$ \\
\hline General Mean & 148.68 & 88.38 & 0.49 & 0.28 & 4.72 & 19.44 \\
\hline CV (\%) & 14.788 & 5.59 & 26.60 & 20.418 & 26.329 & 42.534 \\
\hline $\begin{array}{l}\text { CD at } 5 \% \pm \\
\text { SE (d) }\end{array}$ & $36.48 \pm 17.95$ & NS & NS & $0.094 \pm 0.046$ & $2.06 \pm 1.014$ & $13.514 \pm 6.65$ \\
\hline
\end{tabular}

The non-significant mean values have at least one common letter at $(\mathrm{p}<0.05)$ using Tukey`s Test

Generally, concentration of $\mathrm{Na}^{+}, \mathrm{K}^{+}$or $\mathrm{K}^{+}$: $\mathrm{Na}^{+}$ions in the plant tissue increases with the rise in salinity which may lead to loss of chlorophyll and ultimately leads to leaf chlorosis and necrosis and also bring interruptions in various enzymatic processes in the cytoplasm like process of protein synthesis as reported by Tattini et al., (1994), Lycoskoufis et al., (2005), Naeini et al., (2006), Neocleous and Vasilakakis (2007),
Khoshgoftarmanesh and Naeini (2008), Parvaiz and Satyawati (2008), OkhovatianArdakani (2010).

Based on different observations on pomegranate plants, collected from different locations and grown under salt affected soils, the genotypes could be categorized as salt sensitive or tolerant. It was observed that the genotype 'Jaipur 1' had the most significant 
number of roots at seedling stage. The distinctive vegetative characteristics of genotypes 'Jaipur 1, 'Ajmer 2' and 'Jaipur 3' such as root length, number of shoots, shoot length and number of leaves distinguishes these genotypes from the others and show advantage in terms of cultivation under saline conditions and hence, these genotypes can be used as salinity resistant. Besides, 'Nagaur 1', 'Rajasmand 2' and 'Jaipur 1' had the higher root length. However, the reason of salinity tolerance among these genotypes probably comes back to their adaptability in salt affected soils during long periods of growth years. On the basis of various physiological parameters like proline, RWC, Chlorophyll and $\mathrm{K}^{+} / \mathrm{Na}^{+}$the genotypes, Jaipur 1, 'Ajmer 2' and 'Ajmer 3'are less prone to salt stress as compared to other genotypes. Therefore, on the basis of these studies, we can conclude that genotypes 'Jaipur 3', 'Pali 1', 'Bhagwa' and 'Rajasmand 4' may have some potential to grow under saline conditions which requires further evaluation to identify better salt tolerant genotypes or root stocks.

\section{Acknowledgement}

The authors are highly thankful to the Director, ICAR-CSSRI, Karnal for providing necessary facilities to carry out the research work along with collections of diverse germplasm from different areas.

\section{References}

Anonymous. 2019. National Horticulture Board. Ministry of Agriculture \& Farmers Welfare, Government of India.

Ashraf, M. and Harris, J. C. 2004.Potential biochemical indicators of salinity tolerance in plants. Plant Science.166: 3-16.

Ayers, R. S. and Westcot, D. W. 1985. Water Quality for Agriculture. FAO Irrigation and Drainage Paper 29 Rev. 1., FAO, Rome.

Chatzissavvidis, C., Antonopoulou, C., Therios, I. and Dimassi, K. 2014. Responses of trifoliate orange (Poncirus trifoliata L. Raf.) to continuously and gradually increasing $\mathrm{NaCl}$ concentration. Acta Botanica Croatica. 73 (1): 1-6.

Chauhan, K. S. and Maheshwari, D. L. 1970. Effect of certain plant growth regulators, seasons on type of cuttings and root initiation and vegetative growth in stem cuttings of peach cv. Sharbati. Indian Journal of Horticulture. 27: 136-140.

Devi, J., Bakshi, P., Wali, V. K., Kour, K. and Sharma, N. 2016. Role of auxin and dates of planting on growth of cuttings raised plantlets of phalsa (Grewia asiatica L.). The Bioscan. 11: 535-537.

Doring, J. and Ludders, P. 1986b. Influence of different salts on chlorophyll content, photosynthesis and carbohydrate metabolism of Punica granatum L. Gartenbauwissenschaft. 51: 21-26.

Furr, J. R. and Enriquez, V. M. 1966.Germination of date pollen in culture media. Date growers institute. 43: 24-27

Hoekstra, F. A., Golovina, E. A. and Buitink, J. 2001. Mechanisms of plant desiccation tolerance.Trends in Plant Science.6: 43138 .

Hokmabadi, H., Arzani, K. and Grierson, P. F. 2005. Growth, chemical composition, and carbon isotope discrimination of pistachio (Pistacia vera L.) rootstock seedlings in response to salinity. Crop and Pasture Science.56(2): 135-144.

Hooda, P. S., Sindhu, S. S., Mehta, P. K. and Ahlawat, V. P. 1990. Growth, yield and quality of ber (Zizyphus mauritiana lamk.) as affected by soil salinity. Journal of Horticultural Science and Biotechnology.65:589-593.

Jaleel, C. A., Gopi, R., Sankar, B., Manivannan, P., Kishorekumar, A., Sridharan, R. and Panneerselvam, R. 2007. Studies on germination, seedling vigour, lipid peroxidation and proline metabolism in Catharanthus roseus seedlings under salt stress. South African Journal of Botany. 73(2): 190-195.

Karimi, G., Ghorbanli, M., Heidari, H., KhavariNejad, R. A. and Assareh, M. 2005. The effects of $\mathrm{NaCl}$ on growth, water relations, osmolytes and ion content in 
Kochia prostrata. Biologia Plantarum. 49: 301-304.

Kaur, S. and Kaur, A. 2016.Effect of IBA and PHB on rooting of pomegranate (Punica granatum L.) cuttings cv. Ganesh. Biological Forum-An International Journal 8(2): 203-206.

Khoshgoftarmanesh, A. H. and Naeini, M. R. 2008.Salinity effect on concentration, uptake, and relative translocation of mineral nutrients in four olive cultivars.Journal of Plant Nutrition. 31: 1243-1256.

Kumar, A., Lata, C., Krishnamurthy, S.L., Kumar, A., Prasad, K.R.K. and Kulshreshtha, N. 2017. Physiological and biochemical characterization of rice varieties under salt and drought stresses. Journal of Soil Salinity and Water Quality. 9(2): 167-177.

Kumar, A., Kumar, A., Lata, C., Kumar, S., 2016.Eco-physiological responses of Aeluropus lagopoides (grass halophyte) and Suaedanudiflora (non-grass halophyte) under individual and interactive sodic and salt stress. South African Journal of Botany. 105: 36-44.

Kumar, A., Sharma, S.K., Lata, C., Devi, R., Kulshrestha, N., Krishnamurthy, S.L., Singh, K., Yadav, R.K. 2018. Impact of water deficit (salt and drought) stress on physiological, biochemical and yield attributes on wheat (Triticum aestivum) varieties. Indian Journal of Agricultural Sciences. 88(10): 1624-32.

Lata, C., Kumar, A., Sharma, S.K., Singh, J., Sheokand, S., Pooja, Mann, A., Rani, B. 2017. Tolerance to combined boron and salt stress in wheat varieties: Biochemical and molecular characterization. Indian Journal of Experimental Biology. 55: 321-238.

Lata, C., Soni, S., Kumar, N., Kumar, A., Pooja, Mann, A., Rani, S., 2019.Adaptive mechanism of stress tolerance in Urochondra (grass halophyte) using roots study. Indian Journal of Agricultural Sciences.89: 1050-1052.

Lycoskoufis, I. H., Savvas, D. and Mavrogianopoulos, G. 2005. Growth, gas exchange, and nutrient status in pepper (Capsicum annuum L.) grown in recirculating nutrient solution as affected by salinity imposed to half of the root system.
Scientia Horticulturae. 106: 147-161.

Maas, E. V. and Hoffmann, G. J. 1976. Crop salt tolerance: evaluation of existing data. In: Proceedings International Conference Texas Technical University. 187-197.

Mastrogiannidou, E., Chatzissavvidis, C., Antonopoulou, C., Tsabardoukas, V., Giannakoula, A. and Therios, I. 2016. Response of pomegranate cv. wonderful plants to salinity. Journal of Soil Science and Plant Nutrition. 16(3):621-636.

Melgar, J. C., Syvertsen, J. P., Martinez, V. and Garcia-Sanchez, F. 2008.Leaf gas exchange, water relations, nutrient content and growth in citrus and olive seedlings under salinity. Biologia Plantarum. 52:385390.

Mirfattahi, Z., Karimi, S. and Roozban, M. R. 2017. Salinity induced changes in water relations, oxidative damage and morphophysiological adaptations of pistachio genotypes in soilless culture. Actaagriculturae Slovenica. 109 (2): 291 302

Munns, R. 2002. Comparative physiology of salt and water stress .Plant Cell and Environment. 25: 239-250.

Naeini, M. R., Khoshgoftarmanesh, A. H. and Fallahi, E. 2006.Partitioning of chlorine, sodium, and potassium and shoot growth of three pomegranate cultivars under different levels of salinity. Journal of Plant Nutrition. 29: 1835-1843.

Neocleous, D. and Vasilakakis, M. 2007. Effects of $\mathrm{NaCl}$ stress on red raspberry (Rubusidaeus L. 'Autumn Bliss'). Scientia Horticulturae. 112: 282-289.

Okhovatian-Ardakani, A. R., Mehrabanian, M., Dehghani, F. and Akbarzadeh, A. 2010. Salt tolerance evaluation and relative comparison in cuttings of different pomegranate cultivars. Plant Soil Environment. 56(4): 176-185.

Papadakis, I. E., Veneti, G., Chatzissavvidis, C., Sotiropoulos, T. E., Dimassi, K. N. and Therios, I. N. 2007. Growth, mineral composition, leaf chlorophyll and water relationships of two cherry varieties under $\mathrm{NaCl}$-induced salinity stress. Soil Science and Plant Nutrition. 53: 252-258.

Parvaiz A and Satyawati S. 2008.Salt stress and 
phyto-biochemical responses of plants-a review. Plant Soil and Environment.54: 8899.

Patil, P. K. and Patil, V. K. 1983a.Studies on soil salinity tolerance of sapota.South Indian horticulture.31(1):3-6.

Patil, P. K. and Patil, V. K. 1983b. Influence of ESP on the growth and chemical composition of Jamun (Syzygium cumini Skeels.). Punjab Horticultural Journal. 23(1-2): 69 -78.

Patil, P. K., Patil, V. K. and Ghonsikar, C. P. 1984. Effect of soil salinity on growth and nutritional status of guava. International Journal of Tropical Agriculture.2:337-44.

Perez-Alfocea, F., Estan, M. T., Caro, M. and Bolarín, M. C. 1993. Response of tomato cultivars to salinity. Plant and Soil. 150(2):203-211.

Pooja, Nandwal, A.S., Chand, M., Singh, K., Mishra, A.K., Kumar, A., Kumari, A., Rani, B., 2019. Varietal variation in physiological and biochemical attributes of sugarcane varieties under different soil moisture regimes. Indian Journal of Experimental Biology. 57(10): 721-732.

Singh, A., Kumar, A., Datta, A., Yadav, R.K., 2018. Evaluation of guava (Psidium guajava) and bael (Aegle marmelos) under shallow saline watertable conditions. Indian Journal of Agricultural Sciences.88: 720 725.

Singh, A., Sharma, P.C., Meena, M.D., Kumar, A., Mishra, A.K., Kumar, P., Chaudhari, S.K., Sharma, D.K., 2016. Effect of salinity on gas exchange parameters and ionic relations in bael (Aegle marmelos Correa).Indian Journal of Horticulture.73: 48-53.

Sivstev, M. V., Ponamareva, S. V. and Kuzmetsova, E. A. 1973.Effect of salinization and herbicide on chlorophyllase activity in tomato leaves. Russian Journal of Plant Physiology.20(1): 62-65.

Stancato, G. C., Aguiar, F. F. A., Kanashiro, S. and Tavares, A. R. 2003. Rhipsalis grandiflora Haw propagation by stem cuttings. Scientia Agricola. 56:185-190.

Taha, M. W., El-Sewey, A. and Fadliah, Z. G. 1972.Salt tolerance of grape, guava and olive plants. Alexandria Journal of Agricultural Research.20:123-135.

Taiz, L. and Zeiger, E. 2006.Plant Physiology. 4th Edition, Sinauer Associates Inc. Publishers, Massachusetts.

Tattini, M. 1994. Ionic relations of aeroponicallygrown olive genotypes during salinity stress. Plant and Soil. 161: 251-256.

Tewari, T. N. and Singh, B. B. 1991. Stress studies in lentil (Lens esculenta Moench). II. Sodicity-induced changes in chlorophyll, nitrate and nitrite reductase, nucleic acids, proline, yield and yield components in lentil. Plant and Soil. 136: 225-230.

Wahome, P. K., Jesch, H. H. and Grittner, I. 2001. Mechanisms of salt stress tolerance in two rose rootstocks: Rosa chinensis 'Major' and R. rubiginosa. Scientia Horticulturae, 87(3): 207-216.

\section{How to cite this article:}

Rajkumar, Anshuman Singh, Anita Mann and Yadav, R. K. 2020. Physio-biochemical Variability of Pomegranate Cuttings Collected from Northern India. Int.J.Curr.Microbiol.App.Sci. 9(02): 2049-2058. doi: https://doi.org/10.20546/ijcmas.2020.902.233 